\title{
Testosteron forebygger ikke prostatahyperplasi
}

\author{
Prostata vokste like mye hos \\ menn som fikk testosteron- \\ tilskudd som hos dem som \\ fikk placebo.
}

Prostatas størrelse øker og testosteronnivået synker med økende alder. Mange eldre menn er plaget av benign prostatahypertrofi. Kan behandling med testosteron forsinke normal prostatavekst?

I en studie i Australia og New Zealand ble 114 friske menn over 50 år randomisert til transdermal behandling med enten dihydrotestosteron eller placebo (1). I løpet av 24 måneder vokste prostata, målt med ultrasonografi, like mye i begge grupper. Serumkonsentrasjonen av dihydrotestosteron og dets metabolitter steg og konsentrasjonen av testosteron sank i behandlingsgruppen. Blant dem som fikk dihydrotestosteron, ble beintettheten redusert i spinalcolumna, men ikke i hoftene. Dihydrotestosteron ble seponert hos åtte pga. asymptomatisk økt hematokrit og hos tre pga. økt nivå av prostataspesifikt antigen.

- Denne studien tyder på at behandling med dihydrotestosteron ikke kan forebygge eller forsinke benign prostatahyperplasi, sier professor Johan Svartberg ved Endokrinologisk seksjon, Universitetssykehuset Nord-Norge. - Studien er imidlertid altfor kortvarig og har for få deltakere til å kunne si noe om risikoen for prostatakreft og karsykdommer ved testosteronbehandling.

Den negative effekten på beintettheten

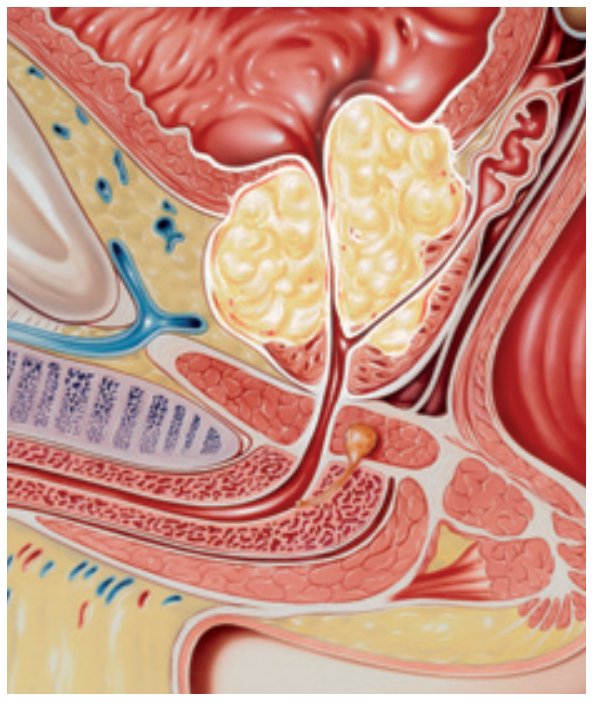

SCANPIX/Science Photo Library

tilsier også varsomhet ved behandling med ikke-aromatiserbare androgener, sier Svartberg.

\section{Petter Gjersvik}

petjense@online.no

Tidsskriftet

\section{Litteratur}

1. Idan A, Griffiths KA, Harwood DT et al. Long-term effects of dihydrotestosterone treatment on prostate growth in healthy, middle-aged men without prostate disease. A randomized, placebo-controlled trial. Ann Intern Med 2010; 153: 621-31.

\section{Celiprolol ved Ehlers-Danlos' syndrom}

Ehlers-Danlos' syndrom er en sjelden sykdom, men likevel den hyppigst forekommende arvelige bindevevssykdommen. Defekter i kollagenfibre kan gi bl.a. leddproblemer, hernier og rupturer av blodkar og andre organer. Celiprolol kan minske risikoen for større komplikasjoner til en tredel i forhold til ingen behandling, ifølge en ny studie (Lancet 2010; 376: 1476-84).

Effekten av celiprolol ble bedømt i en randomisert, åpen studie med blindet vurdering. 53 pasienter med vaskulær EhlersDanlos' syndrom ble randomisert til celiprolol eller ingen behandling. Gjennomsnittlig oppfølgingsperiode var 47 måneder. Studien ble stoppet tidlig pga. fordelene ved behandling. Fem av $25 \mathrm{i}$ intervensjonsgruppen og 14 av $28 \mathrm{i}$ kontrollgruppen fikk arteriell ruptur eller disseksjon (hasardratio 0,36).

\section{Høy mortalitet ved hjertemisdannelser}

Mortaliteten er høy for pasienter med medfødte hjertesykdommer. Den er høyest i tidlig barnealder, men også etter tiårsalderen. Det er konklusjonen i en populasjonsbasert dansk oppfølgingsstudie (Am J Cardiol 2010; 106: 1322-6).

Studien omfattet alle barn under ett år som var blitt diagnostisert med medfødt hjertesykdom i perioden 1977-2006 ( $n=6$ 646). Ca. $20 \%$ av barna hadde også andre misdannelser enn de kardiale, og $11 \%$ var født før termin

Overordnede kumulative mortalitetsestimater ved ett år var $20 \%$, ved ti år $25 \%$ og ved 25 år $28 \%$. For befolkningen i Danmark var det tilsvarende henholdsvis $0,6 \%, 0,8 \%$ og 1,3\%. Mortaliteten varierte betydelig, avhengig av hvilken misdannelse det dreide seg om. Mortaliteten var fallende gjennom studieperioden ved alle misdannelser.

\section{Fra follikulært lymfom til høygradig lymfom}

\section{Genomiske forandringer i tumor- cellene kan gi informasjon om folli- kulært lymfom kan transformeres til diffust storcellet B-cellelymfom.}

Follikulært lymfom rammer om lag 150 voksne og eldre i Norge hvert år. Dagens behandling er basert på kombinasjoner av cellegift, strålebehandling og immunterapi. Selv om behandlingseffekten er god, er residiv vanlig. Hos $30-70 \%$ av pasientene transformeres tilstanden til diffust storcellet B-cellelymfom. Transformasjon er assosisert med behandlingsresistens og kortere overlevelse. Kliniske og molekylære variabler som er assosiert med prognose ved follikulært lymfom, er ikke spesifikke nok til at risikoen for transformasjon til diffust storcellet B-cellelymfom kan beregnes.

Vi har utført genomvide undersøkelser av 100 biopsier fra 44 pasienter med follikulært lymfom (1). Et av målene var å se etter markører for transformasjon. Vi identifiserte et sett med genomiske forandringer som var assosiert med dårlig prognose og transformasjon til diffust storcellet B-cellelymfom. En ekstra kopi av kromosom X i tumorvev fra mannlige pasienter predikerte dårligere overlevelse. Ekstra kopier av kromosomarm $2 \mathrm{p}, 3 \mathrm{q}$ og $5 \mathrm{p}$ var eksklusivt til stede i biopsier fra pasienter med påfølgende transformasjon. Disse forandringene var også assosiert med dårligere overlevelse.

I et oppfølgningsprosjekt er vi nå i gang med å identifisere overuttrykte gener på kromosomarm 2p, 3q og 5p som kan være involvert i prosesser som driver transformasjon. Dette kan bidra til utvikling av behandling som kan redusere risikoen for transformasjon.

\section{Marianne Brodtkorb Eide}

marianne.brodtkorb.eide@rr-research.no Institutt for kreftforskning

Immunologisk avdeling

Radiumhospitalet

Oslo universitetssykehus

\section{Litteratur}

1. Eide MB, Liest $\varnothing \mathrm{K}$ K, Lingjærde OC et al. Genomic alterations reveal potential for higher grade transformation in follicular lymphoma and confirm parallel evolution of tumor cell clones. Blood 2010; 116: 1489-97. 